\title{
Synthesis and Characterization of $\left[(\mathrm{CO})_{4} \mathrm{FeL}-\mathrm{L}\right]$ and $\left[(\mathrm{CO})_{4} \mathrm{FeL}-\mathrm{LFe}(\mathrm{CO})_{4}\right]$ wherein $\mathrm{L}-\mathrm{L}$ is $\mathbf{N}\left(\mathrm{CH}_{2} \mathrm{CH}_{2}\right)_{3} \mathrm{~N}$ and also $\mathrm{P}(\mathrm{NMeNMe})_{3} \mathrm{P}$ in the Latter Complex. Single Crystal $\mathrm{X}$-ray Molecular Structure of $\left[\mathrm{Fe}(\mathrm{CO})_{4} \mathrm{DABCO}\right]$
}

\author{
Robson M. Matos ${ }^{\#, a, b}$ and John G. Verkade ${ }^{*, a}$ \\ ${ }^{a}$ Chemistry Department, Iowa State University, Gilman Hall, Ames, IA, 50011, USA \\ ${ }^{b}$ Departamento de Química, ICEx, Universidade Federal de Minas Gerais, Av. Antônio Carlos, 6627, Pampulha, \\ 31270-901 Belo Horizonte - MG, Brazil
}

\begin{abstract}
Descrevemos aqui a síntese e caracterização de novos compostos mono- e dinucleares derivados de pentacarbonilferro. Eles foram obtidos através da irradiação UV de $\left[\mathrm{Fe}(\mathrm{CO})_{5}\right]$ com o ligante apropriado em THF e foram caracterizados por espectroscopia de RMN de ${ }^{1} \mathrm{H},{ }^{13} \mathrm{C},{ }^{13} \mathrm{C}\left\{{ }^{1} \mathrm{H}\right\},{ }^{31} \mathrm{P}$ e ${ }^{31} \mathrm{P}\left\{{ }^{1} \mathrm{H}\right\}$, por especroscopia na região do IV e análise elementar. A estrutura molecular do $\left[\mathrm{Fe}(\mathrm{CO})_{4}(\mathrm{DABCO})\right]$ determinada por um estudo de difração de raio-X é descrita. O espectro de RMN de ${ }^{13} \mathrm{C}\left\{{ }^{1} \mathrm{H}\right\}$ dos complexos revelam fluxionalidade, provavelmente via pseudorotação de Berry.
\end{abstract}

Herein we report the syntheses and characterization of the novel title mono- and dinuclear compounds from pentacarbonyliron. They were obtained in a stepwise manner by UV irradiation of $\left[\mathrm{Fe}(\mathrm{CO})_{5}\right]$ with the appropriate ligand in THF and were characterized by ${ }^{1} \mathrm{H},{ }^{13} \mathrm{C},{ }^{13} \mathrm{C}\left\{{ }^{1} \mathrm{H}\right\}{ }^{31} \mathrm{P}$ and ${ }^{31} \mathrm{P}\left\{{ }^{1} \mathrm{H}\right\}$ NMR spectroscopy, by IR spectroscopy and by elemental analysis. The single crystal $\mathrm{X}$ ray molecular structure of $\left[\mathrm{Fe}(\mathrm{CO})_{4}(\mathrm{DABCO})\right]$ is described. The ${ }^{13} \mathrm{C}\left\{{ }^{1} \mathrm{H}\right\}$ NMR spectra of each of the title complexes reveal their fluxional behavior, which presumably occurs via Berry pseudorotation.

Keywords: DABCO, tetracarbonyliron, NMR spectroscopy

\section{Introduction}

With the exception of nitrosyl complexes, mononuclear iron tetracarbonyl complexes bearing nitrogen ligands are relatively rare ${ }^{1}$ and most of the reported examples involve aromatic nitrogen ligands such as pyridine, ${ }^{2-5}$ picoline, ${ }^{2}$ pyrazine,$^{3}$ quinoline ${ }^{2}$ and lutidine. ${ }^{2}$ Several aliphatic trialkylaminetetracarbonyl iron complexes have been reported in which the ligand is $\mathrm{NMe}_{3},{ }^{6,7} \mathrm{NEt}_{3},{ }^{6} n-\mathrm{NPr}_{3},{ }^{6} n$ $\mathrm{NBu}_{3},{ }^{6} \mathrm{~N}\left(\mathrm{PhCH}_{2}\right)_{2} \mathrm{Me},{ }^{6}$ hexamethylenetetraamine ${ }^{6}$ or quinuclidine. ${ }^{6}$ The instability of aminetetracarbonyl iron complexes has been attributed to the tendency of nitrogen bases to facilitate disproportionation of iron pentacarbonyl. ${ }^{4,8-11}$ In general, amine tetracarbonyliron complexes must be prepared via indirect routes, as through the use of $\left[\mathrm{Fe}_{2}(\mathrm{CO})_{9}\right],{ }^{12}$ the reaction of $\mathrm{Fe}(\mathrm{CO})_{5}$ with amine

\footnotetext{
\# On leave of absence for a sabbatical year from the Universidade Federal de Minas Gerais.

* e-mail: jverkade@iastate.edu
}

oxide ${ }^{7}$ and the reaction of $\mathrm{HFe}(\mathrm{CO})_{4}^{-}$with $\mathrm{NH}_{2} \mathrm{OSO}_{3}$ to yield $\mathrm{H}_{3} \mathrm{NFe}(\mathrm{CO})_{4}{ }^{13}$

Herein we report the preparation of $\left[\mathrm{Fe}(\mathrm{CO})_{4}(\mathrm{DABCO})\right]$ $\left[\mathrm{DABCO}=\mathrm{N}\left(\mathrm{CH}_{2} \mathrm{CH}_{2}\right)_{3} \mathrm{~N}\right](\mathbf{1})$, and $\left\{\left[\mathrm{Fe}(\mathrm{CO})_{4}\right]_{2}(\mathrm{DABCO})\right\}$ (2) directly from $\left[\mathrm{Fe}(\mathrm{CO})_{5}\right]$ and $\left[\mathrm{Fe}(\mathrm{CO})_{4}(\mathrm{DABCO})\right]$, respectively, under UV photolysis conditions. We also report the preparation of $\left\{\left[\mathrm{Fe}(\mathrm{CO})_{4}\right]_{2}\left[\mathrm{P}(\mathrm{NMeNMe})_{3} \mathrm{P}\right]\right\}(\mathbf{3})$.

\section{Experimental Section}

\section{General procedures}

All reactions were carried out under argon using standard Schlenk techniques, and solvents were freshly distilled under argon before use. 1,4-diazabyciclo[2.2.2] octane (DABCO) and $\left[\mathrm{Fe}(\mathrm{CO})_{5}\right]$ were bought from Aldrich and were used without further purification. 2,3,5,6,7,8-Hexamethyl-2,3,5,6,7,8-hexaaza-1,4diphospha-bicyclo[2.2.2] octane was prepared according to a previously described method. ${ }^{14,15}{ }^{1} \mathrm{H},{ }^{13} \mathrm{C}$ and ${ }^{31} \mathrm{P}$ NMR 


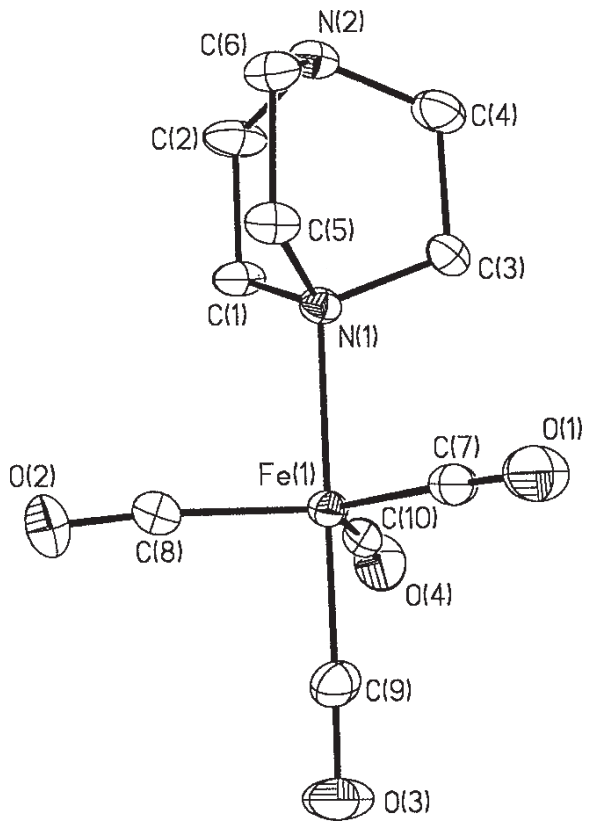

Figure 1. Ortep diagram at $30 \%$ probability of $\mathbf{1}$. Selected bond distances $(\AA)$ and angles $\left({ }^{\circ}\right)$ : $\mathrm{Fe}(1)-\mathrm{C}(9)$ 1.774(6); $\mathrm{Fe}(1)-\mathrm{C}(7)$ 1.806(6); $\mathrm{Fe}(1)-\mathrm{C}(8)$ 1.805(6); $\mathrm{Fe}(1)-\mathrm{C}(10)$ 1.809(6); $\mathrm{Fe}(1)-\mathrm{N}(1)$ 2.096(4); C(9)-Fe(1)-C(7) 88.7(2); C(9)-Fe(1)-C(8) 88.3(3); C(7)$\mathrm{Fe}(1)-\mathrm{C}(8)$ 119.7(3); C(9)-Fe(1)-C(10) 89.2(3); C(7)-Fe(1)-C(10) 124.1(3); $\mathrm{C}(8)-\mathrm{Fe}(1)-\mathrm{C}(10)$ 116.0(3); $\mathrm{C}(9)-\mathrm{Fe}(1)-\mathrm{N}(1)$ 178.5(2); $\mathrm{C}(7)-\mathrm{Fe}(1)-\mathrm{N}(1)$ 90.02(19); C(8)-Fe(1)-N(1) 91.8(2); C(10)-Fe(1)$\mathrm{N}(1) 92.1(2)$.

spectra were recorded on a Bruker DRX400 spectrometer operating at the indicated frequency and the chemical shifts are quoted in ppm using TMS as an internal standard or $\mathrm{H}_{3} \mathrm{PO}_{4}$ as an external reference as appropriate. Infrared spectra were recorded on a Bio-Rad FTS-7 FTIR spectrometer and the frequencies are given without correction. Elemental analyses were carried out at Iowa State University. The molecular weight was measured by Schwarzkopf Laboratories using the "osmometric" technique. Melting points (uncorrected) were determined on a Thomas-Hoover capillary melting point apparatus. UV irradiation was carried out using an Ace photochemical reactor containing a Hanovia 7825-34 mercury vapor lamp. The crystal and molecular structure of $\mathbf{1}$ was carried out by Dr. Ilia Guzei at the University of Wisconsin.

\section{Synthesis of $\left[\mathrm{Fe}(\mathrm{CO})_{4}(\mathrm{DABCO})\right](\mathbf{1})$}

Three different ratios of ligand to carbonyl $(1: 1 ; 2: 1$ and 1:2) were employed. The last ratio gave the best yield. Thus a Schlenk flask was charged with DABCO $(2.00 \mathrm{~g}, 17.9$ $\mathrm{mmol}), \mathrm{THF}(40 \mathrm{~mL})$ and $\left[\mathrm{Fe}(\mathrm{CO})_{5}\right](7.00 \mathrm{~g}, 35.7 \mathrm{mmol})$. The mixture was irradiated for $4 \mathrm{~h}$ and then the excess $\left[\mathrm{Fe}(\mathrm{CO})_{5}\right]$ and the solvent were evaporated under reduced pressure to dryness to yield a red solid that was purified by column chromatography on Florisil and eluted with $n$ hexane. Evaporation of all volatile materials under reduced pressure gave red crystals of the title compound (4.20 g; 84\%). mp 98-100 ${ }^{\circ} \mathrm{C}$, dec., (hexane). ${ }^{1} \mathrm{H}$ NMR data (400.13 $\mathrm{MHz}, \mathrm{CD}_{3} \mathrm{CN} 25^{\circ} \mathrm{C}$ ): $\delta 2.75$ (virt. t, $9.2 \mathrm{~Hz}$ separation, $6 \mathrm{H}$ ), 3.04 (virt t, $9.2 \mathrm{~Hz}$ separation, $6 \mathrm{H}) .{ }^{13} \mathrm{C}\left\{{ }^{1} \mathrm{H}\right\}$ NMR $(100.62$ $\left.\mathrm{MHz}, \mathrm{CD}_{3} \mathrm{CN}, 25^{\circ} \mathrm{C}\right): \delta 48.2\left(\mathrm{~s}, \mathrm{C}^{\mathrm{A}}\right), 59.8\left(\mathrm{~s}, \mathrm{C}^{\mathrm{B}}\right), 217.8(\mathrm{~s}$, CO). ${ }^{13} \mathrm{C}$ NMR data $\left(100.62 \mathrm{MHz} ; \mathrm{CD}_{3} \mathrm{CN}, 25^{\circ} \mathrm{C}\right): \delta 48.2$ (tt, $\left.{ }^{l} J(\mathrm{CH}) 140.9 \mathrm{~Hz},{ }^{2} J(\mathrm{CH}) 5.5 \mathrm{~Hz}, \mathrm{C}^{\mathrm{A}}\right), 59.8\left(\mathrm{tt},{ }^{l} \mathrm{~J}(\mathrm{CH})\right.$ $\left.141.8 \mathrm{~Hz},{ }^{2} J(\mathrm{CH}) 5.5 \mathrm{~Hz}, \mathrm{C}^{\mathrm{B}}\right), 217.8(\mathrm{~s}, \mathrm{CO})$. IR $v_{\max } / \mathrm{cm}^{-1}$ 2047s, 1960s, 1929w and 1895w (CO) (Nujol). Calc. for $\mathrm{C}_{10} \mathrm{H}_{12} \mathrm{~N}_{2} \mathrm{O}_{4} \mathrm{Fe}: \mathrm{C}, 42.89 \%$; H, 4.32\%; N, 10.00\%. Found: $\mathrm{C}$, 41.09\%; H, 4.38\%; N, 9.73\%. Solution molecular weight determination in $\mathrm{CHCl}_{3}: 321$ (calculated 280).

Synthesis of $\left.\left\{\left[\mathrm{Fe}(\mathrm{CO})_{4}\right]_{2}(\mathrm{DABCO})\right]\right\}(\mathbf{2})$

A Schlenk flask was charged with $\left[\mathrm{Fe}(\mathrm{CO})_{4}(\mathrm{DABCO})\right]$ (1) $(2.99 \mathrm{~g} ; 10.7 \mathrm{mmol})$, THF $(40 \mathrm{~mL})$ and $\left[\mathrm{Fe}(\mathrm{CO})_{5}\right]$ $(2.10 \mathrm{~g} ; 10.7 \mathrm{mmol})$. The mixture was irradiated for $48 \mathrm{~h}$ and then the solvent was evaporated under reduced pressure to dryness to yield a red solid that was purified chromatographically on Florisil using acetonitrile as eluent. Fractions 1 and 2 from the column were identified as the desired complex and unreacted $\mathbf{1}$, respectively. Evaporation of the solvent under reduced pressure from the first fraction gave red crystals of the title compound (3.50 g, 74\%). mp120-121 ${ }^{\circ} \mathrm{C}$, dec.(acetonitrile). ${ }^{1} \mathrm{H}$ NMR (400.13 MHz, $\mathrm{CD}_{3} \mathrm{CN}, 25^{\circ} \mathrm{C}$ ): $\delta 3.11(\mathrm{~s}) .{ }^{13} \mathrm{C}\left\{{ }^{1} \mathrm{H}\right\} \mathrm{NMR}$ (100.62 MHz, $\left.\mathrm{CD}_{3} \mathrm{CN}, 25^{\circ} \mathrm{C}\right): \delta 60.1(\mathrm{~s}) ; 218.2(\mathrm{~s}, \mathrm{CO}) .{ }^{13} \mathrm{C}$ NMR (100.62 MHz, $\left.\mathrm{CD}_{3} \mathrm{CN}, 25^{\circ} \mathrm{C}\right): \delta 60.1\left(\mathrm{tt},{ }^{1} \mathrm{~J}(\mathrm{CH})\right.$ $\left.145.68 \mathrm{~Hz},{ }^{3} J(\mathrm{CH}) 5.22 \mathrm{~Hz}\right), 218.2(\mathrm{~s}, \mathrm{CO}) . \mathrm{IR} v_{\max } / \mathrm{cm}^{-1} 2047 \mathrm{~s}$, 1967w and 1931s (CO) (Nujol). Calc. for $\mathrm{C}_{14} \mathrm{H}_{12} \mathrm{~N}_{2} \mathrm{O}_{8} \mathrm{Fe}_{2}$ : C, 37.50\%; H, 2.68\%; N, 6.25\%. Found: C, 37.95\%; H, $2.79 \% ; \mathrm{N}, 6.12 \%$.

Synthesis of $\left\{\left[\mathrm{Fe}(\mathrm{CO})_{4}\right]_{2}\left[\mathrm{P}(\mathrm{NMeNMe})_{3} \mathrm{P}\right]\right\}(\mathbf{3})$

Using a 1:2 ligand-to-metal ratio proved to afford a better yield than a 1:1 ratio and so a Schlenk flask was charged with $\mathrm{P}(\mathrm{NMeNMe})_{3} \mathrm{P}(0.10 \mathrm{~g}, 0.42 \mathrm{mmol})$, THF $(20 \mathrm{~mL})$ and $\left[\mathrm{Fe}(\mathrm{CO})_{5}\right](0.17 \mathrm{~g}, 0.9 \mathrm{mmol})$. The mixture was irradiated with UV light for $4 \mathrm{~h}$ and then unreacted $\left[\mathrm{Fe}(\mathrm{CO})_{5}\right]$ and the solvent were evaporated under reduced pressure to dryness, affording a pale yellow solid that was purified by chromatography on Florisil using benzene as eluent. Evaporation of the benzene under reduced pressure gave pale yellow crystals of the title compound $(0.20 \mathrm{~g}$, 79\%). mp 255-257 ${ }^{\circ} \mathrm{C}$, dec. (benzene). ${ }^{31} \mathrm{P}\left\{{ }^{1} \mathrm{H}\right\}$ NMR (162.0 $\left.\mathrm{MHz}, \mathrm{CDCl}_{3}, 25{ }^{\circ} \mathrm{C}\right): \delta 166.6$ (s). ${ }^{31} \mathrm{P}$ NMR (162.0 MHz, 
$\left.\mathrm{CDCl}_{3}, 25^{\circ} \mathrm{C}\right): \delta 166.6(\mathrm{~m}) .{ }^{1} \mathrm{H} \mathrm{NMR}\left(400.13 \mathrm{MHz}, \mathrm{CD}_{3} \mathrm{CN}\right.$, $25^{\circ} \mathrm{C}$ ): $\delta 3.02$ (virt. t, $6 \mathrm{~Hz}$ separation, $\mathrm{CH}_{3}$ ). ${ }^{13} \mathrm{C}\left\{{ }^{1} \mathrm{H}\right\}$ NMR $\left(100.62 \mathrm{MHz}, \mathrm{CDCl}_{3}, 25^{\circ} \mathrm{C}\right): \delta 37.1$ (overlapping dd, ${ }^{2} J(\mathrm{CP})$ $\left.={ }^{3} \mathrm{~J}(\mathrm{CP})=3.52 \mathrm{~Hz}, \mathrm{CH}_{3}\right), 217.8$ (overlapping $\mathrm{dd}^{2} \mathrm{~J}(\mathrm{CP})=$ $\left.{ }^{5} J(\mathrm{CP})=10.77 \mathrm{~Hz}, \mathrm{CO}\right) .{ }^{13} \mathrm{C} \mathrm{NMR}\left(100.62 \mathrm{MHz}, \mathrm{CDCl}_{3} 25\right.$ $\left.{ }^{\circ} \mathrm{C}\right) \delta 37.1$ (q of overlapping dd, ${ }^{1} J(\mathrm{CH}) 138.14 \mathrm{~Hz},{ }^{2} J(\mathrm{CP})$ $\left.={ }^{3} \mathrm{~J}(\mathrm{CP})=3.52 \mathrm{~Hz}, \mathrm{CH}_{3}\right), 217.8$ (overlapping $\mathrm{dd},{ }^{2} \mathrm{~J}(\mathrm{CP})=$ $\left.{ }^{5} J(\mathrm{CP}) 10.77 \mathrm{~Hz}, \mathrm{CO}\right)$. IR $v_{\max } / \mathrm{cm}^{-1} 2059 \mathrm{~s}, 1992 \mathrm{~s}$ and $1959 \mathrm{vs}$ (CO) (Nujol). Calcd for $\mathrm{C}_{14} \mathrm{H}_{18} \mathrm{~N}_{6} \mathrm{O}_{8} \mathrm{P}_{2} \mathrm{Fe}_{2}: \mathrm{C}, 29.37 \% ; \mathrm{H}$, $3.15 \%$; N, $14.64 \%$. Found: C, $29.40 \% ; \mathrm{H}, 3.23 \%$ N, $14.70 \%$.

\section{Structure determination of $\mathbf{1}$}

Data collection. A yellow crystal was selected under oil under ambient conditions and attached to the tip of a glass capillary. The crystal was mounted in a stream of cold nitrogen at $173(2) \mathrm{K}$ and centered in the X-ray beam by using a video camera. Crystal evaluation and data collection were performed on a Bruker CCD-1000 diffractometer with Mo $\mathrm{K} \alpha$ radiation with a diffractometer to crystal distance of $4.9 \mathrm{~cm}$. The initial cell constants were obtained from three series of $\omega$ scans at different starting angles. Each series consisted of 20 frames collected at intervals of $0.3^{\circ}$ in a $6^{\circ}$ range about $\omega$ with an exposure time of 10 seconds per frame. A total of 64 reflections were obtained. The reflections were successfully indexed by an automated indexing routine built into the SMART program. The final cell constants were calculated from a set of 6257 strong reflections from the actual data collection. The data were collected using the hemisphere data collection routine. The reciprocal space was surveyed to the extent of a full sphere to a resolution of $0.80 \AA$. A total of 20682 data were harvested by collecting three sets of frames with $0.3^{\circ} \mathrm{scans}$ in $\omega$ with an exposure time $30 \mathrm{sec}$ per frame. These highly redundant data sets were corrected for Lorentz and polarization effects. The absorption correction was based on fitting a function to the empirical transmission surface as sampled by multiple equivalent measurements. ${ }^{16}$

Structure solution and refinement. The systematic absences in the diffraction data were uniquely consistent for the space group P2 ${ }_{1 / c}$ which yielded chemically reasonable and computationally stable refinement results. ${ }^{17}$ A successful solution by the direct methods provided most non-hydrogen atoms from the E-map. The remaining nonhydrogen atoms were located in an alternating series of leastsquares cycles and difference Fourier maps. All nonhydrogen atoms were refined with anisotropic displacement coefficients. All hydrogen atoms were included in the structure factor calculation at idealized positions and were allowed to ride on the neighboring atoms with relative isotropic displacement coefficients. There are two independent molecules of the Fe complex in the asymmetric unit. The final least-squares refinement of 572 parameters 6071 data resulted in residuals $R$ (based on $F^{2}$ for $I>2 \sigma$ ) and $w R$ (based on $F^{2}$ for all data) of 0.0580 and 0.1545 , respectively. The final difference Fourier map was featureless. Crystallographic data for $\mathbf{1}$ are summarized in Table 1.

Table 1. Crystal and structure refinement data for $\mathbf{1}$

\begin{tabular}{|c|c|}
\hline Empirical formula & $\mathrm{C}_{10} \mathrm{H}_{12} \mathrm{FeN}_{2} \mathrm{O}_{4}$ \\
\hline Formula weight & 280.07 \\
\hline Temperature & $173(2) \mathrm{K}$ \\
\hline Wavelength & $0.71073 \AA$ \\
\hline Crystal system & monoclinic \\
\hline Space group & $\mathrm{P} 2_{1 / \mathrm{c}}$ \\
\hline Unit cell & $\begin{array}{lll}\mathrm{a}=18.2049(9) \AA & \alpha=90^{\circ} \\
\mathrm{b}=10.5585(5) \AA & \beta=112.020(1) \\
\mathrm{c}=13.8313(7) \AA & \gamma=90^{\circ}\end{array}$ \\
\hline Volume & $2464.7(2) \AA^{3}$ \\
\hline Z & 8 \\
\hline Density (calculated) & $1.510 \mathrm{mg} / \mathrm{m}^{3}$ \\
\hline Absorption coefficient & $1.227 \mathrm{~mm}^{-1}$ \\
\hline $\mathrm{F}(000)$ & 1152 \\
\hline Crystal size & $0.42 \times 0.39 \times 0.24 \mathrm{~mm}^{3}$ \\
\hline Theta range for data collection & 2.28 to $26.38^{\circ}$ \\
\hline Index ranges & $\begin{array}{l}-22<=\mathrm{h}<=21,0<=\mathrm{k}<=13, \\
0<=\mathrm{l}<=17\end{array}$ \\
\hline Reflections collected & 20682 \\
\hline Independent reflections & $5024[\mathrm{R}(\mathrm{int})=0.0391]$ \\
\hline Completeness to theta $=26.38^{\circ}$ & $99.6 \%$ \\
\hline Absorption correction & empirical with SADABS \\
\hline Max. and min. transmission & 0.7571 and 0.6267 \\
\hline Refinement method & Full-matrix least-squares on $\mathrm{F}^{2}$ \\
\hline Data/restraints/parameters & $5024 / 0 / 307$ \\
\hline Goodness-of-fit on $\mathrm{F}^{2}$ & 1.012 \\
\hline Final $R$ indices $[\mathrm{I}>2 \operatorname{sigma}(\mathrm{I})]$ & $\mathrm{R} 1=0.0580, w \mathrm{R} 2=0.1545$ \\
\hline $\mathrm{R}$ indices (all data) & $\mathrm{R} 1=0.0790, \mathrm{wR} 2=0.1623$ \\
\hline Largest diff. peak and hole & 0.787 and -0.462 e. $\AA^{-3}$ \\
\hline
\end{tabular}

\section{Results and Discussion}

The photochemical reaction of $\left[\mathrm{Fe}(\mathrm{CO})_{5}\right]$ with $\mathrm{DABCO}$ in THF affords complex $\mathbf{1}$ in virtually quantitative yield after $4 \mathrm{~h}$. For periods longer than this, formation of a brown precipitate is observed although interestingly, we observed no evidence for the formation of dinuclear $\mathbf{2}$ nor for the disubstituted complex $\left[\mathrm{Fe}(\mathrm{CO})_{3}(\mathrm{DABCO})_{2}\right]$ in this reaction, even when various ratios of reagents were used. We were able to obtain dinuclear 2 by irradiating $\mathbf{1}$ for $48 \mathrm{~h}$ in the presence of $\left[\mathrm{Fe}(\mathrm{CO})_{5}\right]$. However, we were not able to prepare $\left[\mathrm{Fe}(\mathrm{CO})_{3}(\mathrm{DABCO})_{2}\right]$ even when a mixture of $\mathbf{1}$ and excess DABCO was irradiated for $48 \mathrm{~h}$. After this time, a large amount of paramagnetic material was formed. After filtering the THF solution through Florisil, only a mixture containing unreacted materials could be obtained. 
Complexes $\mathbf{1}$ and $\mathbf{2}$ are remarkably stable in the solid state and they can be manipulated in air for long periods of time. However they decompose very easily in solution, especially in hydrocarbons, producing a brown precipitate. Similar observations have been reported for other aminetetracarbonyl complexes. ${ }^{4-6}$

The ${ }^{1} \mathrm{H}$ NMR spectrum of $\mathbf{1}$ in $\mathrm{CD}_{3} \mathrm{CN}$ shows two virtual triplets, with band separations of $9.2 \mathrm{~Hz}$ corresponding to the two sets of chemically equivalent but magnetically nonequivalent hydrogens on each $\mathrm{CH}_{2} \mathrm{CH}_{2}$ moiety in DABCO. The virtually coupled triplet at $\delta 2.75$ is assigned to the $\mathrm{CH}_{2}$ groups bonded to the uncoordinated nitrogen $\left(\mathrm{C}^{\mathrm{A}}\right)$ due to its proximity to the chemical shift of free DABCO $(\delta 2.65)$ whereas the virtually coupled triplet at $\delta$ 3.04 is attributed to the $\mathrm{CH}_{2}$ groups bonded to the coordinated nitrogen $\left(\mathrm{C}^{\mathrm{B}}\right)$. Complex 1 shows a ${ }^{1} \mathrm{H}$ NMR spectrum in which the chemical shifts and multiplet patterns are rather solvent dependent. In $\mathrm{CDCl}_{3}$, its ${ }^{1} \mathrm{H} \mathrm{NMR}$ spectrum exhibits two rather broad singlets at $\delta 2.83$ and $\delta$ 3.06, and in $\mathrm{CD}_{2} \mathrm{Cl}_{2}$ broad singlets are also observed $(\delta$ 2.78 and $\delta 3.03$ ). In benzene- $d_{6}$ solution, however, the singlets are observed at $\delta 1.90$ and $\delta 2.33$. A somewhat smaller difference in proton chemical shifts is observed for free $\mathrm{DABCO}$ in $\mathrm{CD}_{3} \mathrm{CN}(\delta$ 2.65) compared with benzene$d_{6}(\delta 2.47)$.

The ${ }^{13} \mathrm{C}\left\{{ }^{1} \mathrm{H}\right\}$ NMR spectrum of $\mathbf{1}$ exhibits two singlets for the two chemically different $\mathrm{CH}_{2}$ groups in each $\mathrm{CH}_{2} \mathrm{CH}_{2}$ moiety in DABCO, and their assignments were easily made from its heteronuclear decoupling (HMQC) NMR spectrum or by assuming that the chemical shift closer to that of free $\mathrm{DABCO}(\delta 48.4)$ would correspond to the $\mathrm{CH}_{2}$ bonded to the uncoordinated nitrogen, i.e. $\delta 48.2$ $\left(\mathrm{C}^{\mathrm{A}}\right)$ rather than $\delta 59.8\left(\mathrm{C}^{\mathrm{B}}\right)$. The carbonyl region revealed only one signal for the two types of $\mathrm{CO}$ groups, suggesting fluxionality which is rapid on the NMR time scale, a phenomenon commonly observed for substituted pentacarbonyl complexes, ${ }^{3,18-20}$ and also for $\left[\mathrm{Fe}(\mathrm{CO})_{5}\right]$ which is stereochemically nonrigid on the NMR time scale even at $-170{ }^{\circ} \mathrm{C} .{ }^{15,21}$ Our conclusion on this point for $\mathbf{1}$ is supported by its ${ }^{13} \mathrm{C}\left\{{ }^{1} \mathrm{H}\right\}$ NMR spectrum which maintains a singlet for the $\mathrm{CO}$ groups down to $-80^{\circ} \mathrm{C}$. The process is generally assumed to proceed through Berry pseudorotation which, because bond rupture is not involved, spin-spin coupling is preserved. ${ }^{3,12,15,17}$ It had been believed at one time that exchanging one $\mathrm{CO}$ with a ligand different in its $\sigma$-donor and $\pi$-acceptor properties (e.g., pyridine) would inhibit pseudorotation by virtue of a strong $\sigma$-donor capability and its extremely weak $\pi$ acceptor property, which would create a preference for the ligand to bond in an axial position. However, the ${ }^{13} \mathrm{C}$ NMR spectrum of $\left[\mathrm{Fe}(\mathrm{CO})_{4}\right.$ py] showed no change from room temperature to temperatures as low as $-100{ }^{\circ} \mathrm{C} .{ }^{3}$ The ${ }^{13} \mathrm{C}$ NMR spectrum of $\mathbf{1}$, as expected, shows two triplets of triplets for each $\mathrm{CH}_{2}$ group (with ${ }^{1} J_{\mathrm{CH}}$ and ${ }^{3} J_{\mathrm{CH}}$ coupling constants in the expected range) and a singlet for the $\mathrm{CO}$ groups.

The IR spectrum of $\mathbf{1}$ exhibits four bands in the $\mathrm{CO}$ region (see Experimental) with the lowest reciprocal wave length displaying a very weak intensity. For a complex of $\mathrm{C}_{3 \mathrm{v}}$ symmetry only three bands are normally expected unless splitting of the E mode occurs. ${ }^{22}$ The normally axial ligand placement in $\mathrm{Fe}(\mathrm{CO})_{4} \mathrm{~L}$ complexes has been amply documented by X-ray diffraction studies, ${ }^{23-25}$ including $\left[\mathrm{Fe}(\mathrm{CO})_{4}\left(\mathrm{PHPh}_{2}\right)\right]$, for example, for which splitting of the $\mathrm{E}$ mode has also been observed. ${ }^{21}$

Despite the tendency for tetracarbonyl iron(0) amine complexes to decompose in hydrocarbon solvents, ${ }^{4-6}$ a yellow single crystal of $\mathbf{1}$ suitable for X-ray study was obtained from an $n$-hexane solution of this complex. The molecular structure of $\mathbf{1}$ (Figure 1) is a trigonal bipyramid with the DABCO ligand in an axial position, as would be expected due to the lack of $\pi$-acceptor character of the ligand. The Fe-N bond length [2.096(4) $\AA$ ] is longer than in $\left[\mathrm{Fe}(\mathrm{CO})_{4}\right.$ (pyridazine) $][2.013(5) \AA],{ }^{26}\left[\mathrm{Fe}(\mathrm{CO})_{4}(\right.$ py) $]$ $[2.046(5) \AA],{ }^{3}\left[\mathrm{Fe}(\mathrm{CO})_{4}\right.$ (pyrazine) $][2.031(2) \AA]^{3}$ and $\left[\mathrm{CpFeC}_{5} \mathrm{H}_{4}-4-\mathrm{CHCH}-\mathrm{py}-\mathrm{Fe}(\mathrm{CO})_{4}\right][2.041(4) \AA]^{27}$ by more than three times the esd values. However, this is not unexpected since in complex $\mathbf{1}$ the donating nitrogen lone pair has $\mathrm{sp}^{3}$ character whereas the examples cited possess nitrogens with an $\mathrm{sp}^{2}$ lone pair in which the s character is augmented. To the best of our knowledge, 1 represents the first example of a complex of the type $\left[\mathrm{Fe}(\mathrm{CO})_{4}(\right.$ amine $\left.)\right]$ whose structure has been determined by X-ray crystallographic means in which the amine is aliphatic. The $\mathrm{Fe} \mathrm{C}_{(\mathrm{ax})}$ bond distance [1.774(6) $\AA$ ] found for complex $\mathbf{1}$ is very close to those in $\left[\mathrm{Fe}(\mathrm{CO})_{4}\right.$ (pyridazine) $][1.765(7) \AA],{ }^{26}$ $\left[\mathrm{Fe}(\mathrm{CO})_{4}(\mathrm{py})\right][1.772(7) \AA],{ }^{3}\left[\mathrm{Fe}(\mathrm{CO})_{4}\right.$ (pyrazine) $][1.774(4)$ $\AA]^{3}$ and $\left[\mathrm{CpFeC}_{5} \mathrm{H}_{4} \mathrm{CHCH}-\mathrm{py}-\mathrm{Fe}(\mathrm{CO})_{4}\right][1.760(6) \AA] .{ }^{27}$ The $\mathrm{Fe}^{-\mathrm{C}_{(\mathrm{eq})}}$ bond distances (avg. $1.807 \AA$ ) are in the normal range found for complexes of the type $\left[\mathrm{Fe}(\mathrm{CO})_{4} \mathrm{~L}\right]{ }^{3,26,27}$

The dinuclear complex 2 features a singlet at $\delta 3.11$ in its ${ }^{1} \mathrm{H}$ NMR spectrum, corresponding to the two chemically equivalent $\mathrm{CH}_{2}$ groups. Its ${ }^{13} \mathrm{C}\left\{{ }^{1} \mathrm{H}\right\} \mathrm{NMR}$ spectrum consists of a singlet due to the $\mathrm{CH}_{2}$ groups $(\delta 60.1)$ and, similarly to the ${ }^{13} \mathrm{C}\left\{{ }^{1} \mathrm{H}\right\}$ NMR spectrum of $\mathbf{1}$, only one signal corresponding to the $\mathrm{CO}$ groups at $(\delta$ 218.2) is present. The ${ }^{13} \mathrm{C}$ NMR spectrum of this compound displays a triplet of triplets at $\delta 60.1$ with a one-bond $\mathrm{HC}$ coupling constant of $145.68 \mathrm{~Hz}$ and a three-bond proton-carbon coupling constant of $5.22 \mathrm{~Hz}$. As expected, the $\mathrm{CO}{ }^{13} \mathrm{C}$ resonance appears as a singlet at $\delta 218.2$ owing to rapid pseudorotation. The IR spectrum of 2 reveals three bands 
in the $\mathrm{CO}$ region $\left(2047,1967\right.$ and $\left.1931 \mathrm{~cm}^{-1}\right)$.

Unlike $\mathrm{DABCO}, \mathrm{P}(\mathrm{NMeNMe})_{3} \mathrm{P}$ in the presence of $\left[\mathrm{Fe}(\mathrm{CO})_{5}\right]$ under photolysis conditions does not yield the corresponding mononuclear complex $\left\{\left[\mathrm{Fe}(\mathrm{CO})_{5}\right]\right.$ $\left.\left[\mathrm{P}(\mathrm{NMeNMe})_{3} \mathrm{P}\right]\right\}$ even when the reaction is carried out with a 1:1 ratio of the reactants. The products isolated from the reactions using a 1:1 or 1:2 ligand-to-metal ratio are the same, namely, $\left\{\left[\mathrm{Fe}(\mathrm{CO})_{5}\right]_{2}\left[\mathrm{P}(\mathrm{NMeNMe})_{3} \mathrm{P}\right]\right\}(3)$ in the latter case and excess ligand in the former. The ${ }^{31} \mathrm{P}\left\{{ }^{1} \mathrm{H}\right\}$ NMR spectrum of 3 shows a singlet at $\delta 166.6$ whereas the ${ }^{31} \mathrm{P}$ NMR spectrum consists of a multiplet containing nine bands centered at the same chemical shift, corresponding to the $\mathrm{X}$ part of an $\mathrm{A}_{9} \mathrm{XX}^{\prime} \mathrm{A}_{9}$ ' virtually coupled second order spectrum. The ${ }^{1} \mathrm{H}$ NMR spectrum of $\mathbf{3}$ exhibits a virtually coupled triplet (indicative of strong PP coupling) corresponding to the A part of an $\mathrm{A}_{9} \mathrm{XX}^{\prime} \mathrm{A}_{9}$ ' spectrum at $\delta 3.02$ with a band separation of $6 \mathrm{~Hz}$. Its ${ }^{13} \mathrm{C}\left\{{ }^{1} \mathrm{H}\right\}$ NMR spectrum consists of two apparent triplets $(\delta 37.1$ and $\delta 217.8)$. We assign the upfield triplet to the $\mathrm{CH}_{3}$ protons which are coupled equally to the two phosphorus atoms $\left({ }^{2} J_{\mathrm{CP}}={ }^{3} J_{\mathrm{CP}}=3.52 \mathrm{~Hz}\right)$ giving rise to an overlapping pair of doublets. Similarly, the lowfield triplet is attributed to accidentally equal coupling of the $\mathrm{CO}$ carbons to the two phosphorus nuclei $\left({ }^{2} J_{\mathrm{CP}}={ }^{5} J_{\mathrm{CP}}=\right.$ $10.77 \mathrm{~Hz}$ ). While it may seem odd that the five-bond CP coupling is approximately as large as its two-bond counterpart, it should be noted that there are three throughbond pathways for the latter coupling to occur. That spinspin coupling in a diphosphorus cages of this type can indeed be substantial and is supported by the observation that the $\mathrm{PP}$ coupling in $\mathrm{P}\left(\mathrm{CH}_{2} \mathrm{NMe}\right)_{3} \mathrm{P}$ is $27 \mathrm{~Hz}$ and is $116 \mathrm{~Hz}$ in $\mathrm{S}=\mathrm{P}\left(\mathrm{CH}_{2} \mathrm{NMe}\right)_{3} \mathrm{P}=\mathrm{S} .{ }^{28}$ Like the DABCO complexes $\mathbf{1}$ and $\mathbf{2}$, complex $\mathbf{3}$ is also fluxional on the NMR time scale, since only one ${ }^{13} \mathrm{C}$ chemical shift $(\delta 217.8)$ is observed.

\section{Acknowledgements}

We thank the Donors of the PRF administered by the American Chemical Society for funding this work. RMM thanks CNPq-Brazil for a travel award and UFMG for the award of a sabbatical year.

\section{Supplementary Material}

Crystallographic data (excluding structure factors) for the structures in this paper have been deposited with the Cambridge Crystallographic Data Centre as supplementary publication no CCDC 176925. Copies of the data can be obtained, free of charge via ww.ccdc.cam.ac.uk/conts/ retrieving.html (or from the Cambridge Crystallographic Data Centre, CCDC, 12 Union Road, Cambridge CB2 1EZ, UK; fax: +44 1223 336033; or e-mail: deposit@ccdc.cam.ac.uk).

\section{References}

1. Whitmire, K. H. In Comprehensive Organometallic Chemistry II; Abel; E. A.; Stone, F. G. A.; Wilkinson, G., eds.; Elsevier Science: Oxford, UK, 1995, vol. 7, p.1.

2. Shubert, E. H.; Sheline, R. K.; Inorg. Chem. 1966, 5, 1071.

3. Cotton, F. A.; Troup, J. M.; J. Am. Chem. Soc. 1974, 96, 3438.

4. Fanchinetti, G.; Fochi, G.; Funaioli, T.; Zanazzi, P. F.; J. Chem. Soc., Chem. Commun. 1987, 87.

5. Mealli, C.; Proserpio, D. M.; Fachinetti, G.; Funaioli, T.; Fochi, G.; Zanazzi, P. F.; Inorg. Chem. 1989, 28, 1122.

6. Birencwaig, F.; Shamai, H.; Shvo, Y.; Tetrahedron Letters 1979, 31, 2947.

7. Elzinga, J.; Hogeveen, H.; J. Chem. Soc., Chem. Commun. 1977, 705 .

8. Hieber, W.; Werner, R.; Chem. Ber. 1957, 90, 286.

9. Hieber, W.; Angew. Chem. 1960, 72, 795.

10. Hieber, W.; Kahlen, R.; Chem. Ber. 1958, 91, 2223.

11. Edgell, W. F.; Yang, M. T.; J. Am. Chem. Soc. 1966, 88, 4839.

12. Shriver, D. F.; Whitmire, K. H., In Comprehensive Organometallic Chemistry, Wilkinson, G.; Stone, F. G. A.; Abel, E. W. eds., Pergamon Press: Oxford, UK, 1982, vol. 4, p. 243.

13. Hieber, W.; Beutner, H.; Angew. Chem., Int. Ed. Engl. 1962, $1,116$.

14. Goetze, R.; Nöth, H.; Payne, D. S.; Chem. Ber. 1972, 105, 2637.

15. Nöth, H. ; Ullmann, R.; Chem. Ber. 1974, 107, 1019.

16. Blessing, R. H.; Acta Cryst. 1995, A51, 33.

17. All software and sources of the scattering factors are contained in the SHELXTL (version 5.1) program library (G. Sheldrick, Bruker Analytical X-Ray Systems, Madison, WI).

18. Adams, R. D.; Cotton, F. A.; In Dynamic Nuclear Magnetic Resonance Spectroscopy, Jackman, L. M.; Cotton,F. A., eds., Academic Press: New York, 1975, p. 489.

19. Udovich, C. A.; Clark, R. J.; Hass, H.; Inorg. Chem. 1969, 8, 1066.

20. Langford, G. R.; Akhtar, M.; Ellis, P. D.; MacDiarmid; A. G.; Odom, J. D.; Inorg. Chem. 1975, 98, 5728.

21. Jesson, J. P.; Meakin, P.; J. Am. Chem. Soc. 1973, 95, 1344.

22. Darensbourg, D. J.; Nelson, III, H. H.; Hyde, C. L.; Inorg. Chem. 1974, 13, 2135.

23. Riley, P.; Davis, R. E; Inorg. Chem., 1980, 19, 159.

24. Pickardt, J.; Rosch, L.; Schumann, H.; J. Organomet. Chem. 1976, 107, 241.

25. Kilbourn, B. T.; Raeburn, U. A.; Thompson, D. T.; J. Chem. Soc. (A) 1969, 1906.

26. Cotton, F. A.; Hanson, B. E.; Isr. J. Chem. 1977, 15, 165.

27. Lee, I. S.; Lee, S. S.; Chung, Y. K.; Kim, D.; Song, N. W.; Inorg. Chim. Acta, 1998, 279, 243.

28. P. M. Stricklen; J.G. Verkade, unpublished work.

Received: June 21, 2002

Published on the web: December 13, 2002 